\title{
Efforts To Improve The Learning Activity And Learning Outcomes Of Physics Students With Using A Problem-Based Learning Model
}

\author{
Maria Yosephien Retna Tinon Kawuri ${ }^{1}$, Ishafit ${ }^{2}$, Suritno Fayanto ${ }^{3}$ \\ 1,2,3 Department of Master in Physics Education, University of Ahmad Dahlan, Indonesia \\ Coressponding Author. E-mail: \\ 1 myretna@gmail.com
}

Received: 24 Juni 2019

Accepted: 28 Juli 2019

Online Published: 30 Juli 2019

\begin{abstract}
Abstrak
Student learning outcomes become a problem because it does not fullfill the minimum criteria set by the curriculum. So, the goal of this investigation to implement a problem-based learning model as an effort to improve student learning activities and outcomes. This model of research is a classroom action research divided into two cycles. The study conducted at High School 1 Piyungan class X MIPA 1 totaling 35 students consisting of 15 male and 20 female, the topic used the momentum and impulse of semester 2 . The research instrument is observation sheet, achievement test, and questionnaire. The results of the analysis learning model with problem-based learning can increase the activity of studying physics class X MIPA1. Improved physics learning activities of class X MIPA 1 students at High School 1 Piyungan with problem-based learning for the academic year 2018/2019 from the first cycle at the first meeting and the second meeting increased from $84.75 \%$ to $91.11 \%$ which was 6.36 In the second cycle there was an increase from $85.28 \%$ to $91.85 \%$, an increase of $6,57 \%$.
\end{abstract}

Kata Kunci: Problem-Based Learning, Learning Activity, Learning Outcomes, Action Classroom

How to cite this article :

Kawuri, M., Ishafit, I., \& Fayanto, S. (2019). Efforts To Improve The Learning Activity And Learning Outcomes Of Physics Students With Using A Problem-Based Learning Model. IJIS Edu : Indonesian Journal of Integrated Science Education, 1(2). doi:http://dx.doi.org/10.29300/ijisedu.v1i2.1957 


\section{PENDAHULUAN}

Curriculum 2013 applies the scientific learning approach, the approach students required to be more active and critical in the class (Nugraha \& Suherdi, 2017). The reality in the field, especially physics learning, needs to use approaches that more related to problems and related to everyday events (Shohimin, 2016). In this intended that students' understanding of physics more deeply embedded in the brain and does not cause a misconception of the material studied. Wina said that learning in schools too cramped students' minds by sharing memorizing teaching materials but did not direct students to develop and build character and student abilities (Wina Sanjaya, 2010). Conceptualization and information by students less useful because one-way teachers only communicate the material. Understanding the concepts in learning very important this will affect attitudes, decisions, and ways to solve problems, meaningful learning significant (Trianto, 2009).

Seeing the reality in High School 1 Piyungan Bantul, there are still many students who do not understand the material studied. There are still teachers when learning less varied in applying the learning model. In addition, when learning takes place students are less daring to ask there is material that does not understand, students less daring to express opinions, students are still joking and crowded during learning, students less responding the assignment given by the teacher.

Learning will be optimal and meaningful one of which can be achieved the teacher creative and innovative and always strives continuously to develop the character of the teaching and education process in the classroom ( Nana Sudjana, 2002; Fatmawati et al., 2019). Improving the quality of learning in the classroom will also affect the quality of education in general. Efforts to improve and improve the quality of education in the classroom must perform, one such effort by conducting classroom action research (Mulyasa, 2011; Nurhayati \& Rosmaiyadi, 2017).

Classroom Action Research is a research model developed in class or a form of study that reflective action actors, to increase the rational stability of their actions carrying out tasks, deepen understanding of the actions taken, and improve where practices learning carried out (Rizal, 2015). Through class actions deficiencies or weaknesses that occur the teaching and learning process identified and detected for the right solutions (Kunandar, 2008). Classroom action research is research carried out in the classroom when learning takes place, to enhance the characteristic of learning in the classroom (Warso, 2016).

Based on observations in High School 1 Piyungan Bantul, it shows the learning process implemented still conventional. In this because of the low interest in reading students, both textbooks or other learning resources the support the teaching and learning process in the classroom. Teachers are more active in the learning process at the school that students are passive, thus student learning outcomes still lacking even under minimum completeness criteria. The minimum completion criteria of High School 1 Piyungan reached an average of 75 . The low scores of physics students caused students being unable to solve problems according to the stages of problem-solving and students' interest in learning physics that was still low. Many variables can affect student success, but the most important is classroom teaching and learning disabilities. It is important to remember that all students do not study in the same way or at the same level. Students are like leaves in a tree; no two are the same. Just as leaves come in unique colors, shapes, and sizes, each student has their learning style (Bagus Shandy Narmaditya \& Dwi Wulandari, 2017).

Looking at the existing problems, the right learning model, according to the material studied that student learning outcomes increase. The learning model that will be used in classroom action research using a problem-based learning model. Problem Based Learning is a learning model to solve problems that emphasize the meaningfulness of students, which can serve as a springboard for study and resolution of issues (Erda, Razak, \& Sumarmin, 2018). Learning that starts from a challenge, expected that students are more interested and active in solving problems faced and associated with difficulties in everyday life (Camacho \& Christiansen, 2018). Learning begins from real issues will be more meaningful for students that the understanding and results of student physics learning increases. Students' ability in problem-solving not just an accumulation of knowledge, but is a development of cognitive skills that help students to analyze and be able to produce meaningful solutions. Even the problem-solving ability the highest learning outcome (Suyatno, 2009). If the problem presented in the form of problem-based learning able to attract students that they do not feel bored while studying (Khusna, Syamrurizal, \& Azwir Anhar, 2018). In other words, using the problem-based model of learning in education provides an opportunity for students to develop reasoning skills and design their learning (Mardian \& Yerizon, 2018). 
Based on various reasons, the authors examine the efforts to increase physics learning activities and results of class X MIPA 1 Students with the problem-based learning model at the high school 1 Piyungan momentum and impulse. The purpose of this study to describe whether learning with Problem-Based Learning models can improve physics learning outcomes in the momentum and impulse material of class X MIPA 1 students and explain whether learning with Problem-Based Learning models can improve learning activities physics in the momentum material and impulse of class X MIPA 1 students.

\section{METODE}

\section{Setting Research}

The subjects of this study were students of class X MIPA 1 High School 1 Piyungan, 35 students consisted of 15 male students and 20 female students. The object research is the activity and learning outcomes of students with PBL models for momentum material. The study was conducted for four months, namely the month starting from January to April 2019. The survey conducted in High School 1 Piyungan Bantul, namely students of class X MIPA 1 even semester of the school year 2018/2019. Retrieval of students in grade X MIPA 1 based on observations and student learning outcomes in semester one still not good; many students must remediate to achieve the minimum completeness criteria. The researcher teaches students in class X MIPA1 every Wednesday for 2 hours of study and Friday for 1 hour of study.

\section{The Procedure of Classroom Action Research}

This research includes qualitative research and is classroom action research (Sugiyono, 2012). This study uses two cycles. Each cycle consists of 4 stages of activity, namely: (1) planning, (2) action, (3) observation, (4) reflection.

- First Cycle

Planing: (1) Make a plan learning program. The plan for implementing learning spelled out from the syllabus about momentum. The plan learning program adjusted and applies the problembased learning model that learning takes place actively and pleasantly, and independence in accordance with the talents, interests and physical and psychological development of students; (2) Prepare a student worksheet for group discussion; (3) Arrange and prepare the observation sheet and attitude scale (4) Make a grid of questions and determine indicators of success; (5) Preparing pretest and posttest questions; (6) Prepare a test question.
Action: This ongoing stage is the realization of all educational theories and teaching techniques prepared in advance. The steps taken the education, of course, refer to the applicable curriculum and are used in accordance with the relevant curriculum and used in the research location, and the results expected to be in the form increasing the active learning process that aims to improve student learning outcomes. The action used in the study use the Problem-Based Learning model that adjusted to the action plan that prepared and prepared in advance. The activities in this study are divided into two cycles, that the research results as expected. Some will be done in this regard, as follows: (1) Say hello to students; (2) The teacher checks the presence of students, (3) The teacher held a pretest about momentum material; (4) The teacher guides students in forming groups; (5) Students read literacy from books about momentum material; (6) The teacher conveys the task of questions about momentum in the form of student worksheets; (7) Students in groups complete the assignment given the teacher; (8) each group presents the results of their group work; (9) The teacher provides other groups the opportunity to respond to the results of group work; (10) The teacher provides answers to the assignments given to students; (11) The teacher together with the students make conclusions from the results of discussion, the teacher holds a posttest; (12) The teacher gives the final test in the first cycle to find out the student learning outcomes

a) Observation: The teacher or collaborator observes the activities the teacher and students in learning, then does a reflection that there is an improvement in the next education. Representations made to determine the extent to which students know and understand what has communicated during learning. Observations made on students and teachers by observers

b) Reflection: At this stage the activities carried to reflect the events carried out by students during the implementation of learning, whether students play an active role in education, whether students able to understand the material studied, whether there is an increase in learning activities, whether there is an increase in learning outcomes after using problem-based learning. The intended as a reflection of the teacher or student in the next cycle.

- Second Cycle

a) Planing: (1) Determine the problems to be corrected which include active discussion, cohesiveness, number of questions and improvement of student learning outcomes; 
(2) Prepare a learning Implementation plan; (3) Learning Implementation plan compiled about momentum conservation law, collision, restitution coefficient, application of collision; (4) Prepare instruments to see changes in students that include student activity, learning situations, and student learning outcomes.

b) Action: The activities in this study intended that the research results are as expected. Some will be done in this regard, as follows: (1) Say hello to students; (2) The teacher checks the presence of students, (3) The teacher held a - one about the collision material; (4) The teacher guides students in forming groups; (5) Students read literacy from books about collision material; (6) The teacher submits the task of questions about collisions in the form of student worksheet; (7) Students in groups complete the assignment given by the teacher; (8) each group presents the results of their group work; (9) The teacher provides other groups the opportunity to respond to the effects of group work; (10) The teacher provides answers to the assignments given to students; (11) The teacher together with students makes conclusions from the results of the discussion; (12) The teacher holds a posttest; (13) The teacher gives the final test in the second cycle to find out the student learning outcomes.

c) Observation: Observations carried out during learning by collaborators. At this stage directed to identify problems, collect data, in discussions there is an increase in togetherness and cohesiveness in solving problems that there is an increase in understanding of the material about collisions that carried out which towards students and teachers by observers.

d) Reflection: Observational data obtained during the learning process in the form of activeness and student learning outcomes analyzed qualitatively. After being investigated, reflected, and evaluated. The evaluation used to find out whether the actions carried out are by the expected or not. Reflections made to make improvements in the first cycle.

\section{Data Collection and Analysis Date}

Data collection techniques used three techniques, namely the observation method, test method, and questionnaire method. With the success indicator requirements, namely: (1) Increasing the learning success of the XIPA class students of High School 1 Piyungan 2018/2019 in the momentum material marked an average score of 75 according to individual minimal completeness criteria and classical completeness reaching 85\%; (2) Increased student learning activities characterized the activities of students to ask questions, answer questions, complete assignments on time according to the momentum material with the Problem-based learning models. To calculate the percentage of completeness in learning the classically used formula (Sudjana, 1995) :

$$
P=\frac{\sum A}{\sum B} \times 100 \%
$$

Where : $P=$ Percentage of completeness, $\Sigma A=$ Number of students get grades $\geq 70, \Sigma B=$ Students take the test

Classical learning completeness stated to be successful if the percentage of students complete learning or students get a value of $\geq 70$ greater or equal to $85 \%$ of the total number of students. The results of this analysis used as reflection material to carry out further planning the next meeting and cycle and the results of the analysis also used as a reflective material in improving the learning design or even as a consideration in determining the right learning method.

\section{RESULT AND DISCUSSION}

The action research that will be carried out on class X MIPA 1 students in High School 1 Piyungan see that student physics learning outcomes are still low. Students less active during learning. Likewise, there are still many students who are shyly asking their material that is not clear, and students are still not confident to express their opinions or answers to questions from the teacher. At the time of learning, there was also student were busy with peers, some engrossed in playing cellphones. There is a task that must complete the student does not give a positive response delaying the collection of tasks that should be collected. Learning is still conventional, and many students are sleepy and less interested in learning physics. The results of the tests also showed that many students had not finished out of 35 students, only 14 children whose grades were above minimum completeness criteria, which was $40 \%$.

Based on these questions, classroom action research conducted on class X MIPA 1 High School 1 Piyungan with learning using a problem-based learning model on momentum material and collisions. Problem-based learning expected to improve the activities and results of student physics learning. problem-based learning will make the student learning atmosphere productive and conducive, and students can practice solving real problems in daily life by the material studied. 
The implementation of learning divided into five activities, namely the core activities of the first activity which consist of stages of student orientation to the obstacle; arrange pupils to study; guide individual and group inquiries; develop and display work; analyze and evaluate the learning process; and the last activity.

Based on the implementation of learning carried out the teacher in the first cycle to the second cycle there an increase in the aspects carried out the teacher. In this after the study on the first syllabus of the teacher given input, collaborator for further improvement of learning, namely in the second cycle. The indicators used to assess student activity during the learning process are: (a) Listening to teacher explanations, (b) Reading reference material / literacy materials, (c) Asking questions, (d) Working on assignments, (e) Collaboration in groups, ( $\mathrm{f}$ ) Problem solving, (g) Convey opinions. This indicator certainly a benchmark for improving teacher activities in subsequent learning - the recapitulation of the percentage of teacher activities at each silk line presented in Table 1.
Table 1. Recapitulation Results of Teachers at Each Cycle

\begin{tabular}{ccc}
\hline Cycle & Category & Percentage \\
\hline I & Quite active & $71 \%$ \\
II & Active & $78 \%$ \\
\hline
\end{tabular}

From Table 1 it shows an increase and improvement in teaching activities in the implementation of learning from the percentage of $71 \%$ in the first cycle to $78 \%$ in the second cycle. The means the lack of aspects in the first cycle improved the teacher in the second cycle that it shows a change in improvement in learning.

Observation of students' activeness while participating in learning with problem-based learning conducted collaborator shows an increase from cycle 1 to cycle 2 . The shows that students at the time of learning cycle 1 were still less active, especially during discussions where initially children were still shy about asking questions and raising opinions. The results of observations of student activities in each cycle shown in Table 2.

Table 2. Comparison of Percentage of Student Activities When Learning

\begin{tabular}{ccccc}
\hline \multirow{2}{*}{ Cycle } & \multicolumn{2}{c}{ Meeting I } & \multicolumn{2}{c}{ Meeting II } \\
\cline { 2 - 5 } & Category & Percentage & Category & Percentage \\
\hline I & Active & $84,75 \%$ & Very active & $91,11 \%$ \\
II & Active & $85,28 \%$ & Very active & $91,85 \%$ \\
\hline
\end{tabular}

Based on Table 2 can be compared to the activities of students from the first meeting in the first cycle from $84.75 \%$, up to $91.11 \%$ in the second meeting. In the second cycle, the first meeting of student activity rose from $82.28 \%$ with the current category being a very active category with a percentage of $91.85 \%$. It concluded that there is an increase in student activity in learning with problem-based learning from cycle I to cycle I. This is because during the learning process students are asked to develop and present the results of their discussion in front of the class; in the meantime, other students asked to respond to the effects of group discussions presented that there is reciprocal interaction between students and students and students and teachers(Laili \& Lufri, 2019).

In learning problem-based learning models students faced with problems that adapted the material studied in this case material momentum and impulses, students asked work on quiz questions in groups to discuss and solve problems with their groups then the results of group work presented in front of the class. The results of the discussion and group work were by rated the teacher and the group that got the highest score given an award - the value of student learning outcomes in cycle one presented in Table 3. 
Table 3. Value Results Discussion First Cycle

\begin{tabular}{|c|c|c|c|}
\hline Group & Values First Meeting & Values Second Meeting & Average \\
\hline 1 & 70 & 80 & 75 \\
\hline 2 & 75 & 75 & 75 \\
\hline 3 & 40 & 60 & 50 \\
\hline 4 & 70 & 60 & 65 \\
\hline 5 & 80 & 80 & 80 \\
\hline 6 & 85 & 90 & 88 \\
\hline 7 & 60 & 60 & 60 \\
\hline
\end{tabular}

From the results, the first cycle (Table 3) the first meeting turned out there were still groups that were less active in solving problems, namely groups $1,3,4$, and 7 . However, in the second meeting, there had been an increase; namely, groups that completed were groups 3, 4 7. This means that students have begun to understand and interested in discussing with friends to complete the assignments given by the teacher. The shortcomings of the first cycle of discussion as a reflective material for improvement in period II. The results of the second cycle discussion are like Table 4

Table 4 . Value Results Discussion Second Cycle

\begin{tabular}{cccc}
\hline Group & Values First Meeting & Values Second Meeting & Average \\
\hline 1 & 75 & 75 & 75 \\
2 & 80 & 80 & 80 \\
3 & 75 & 80 & 78 \\
4 & 75 & 75 & 75 \\
5 & 85 & 90 & 88 \\
6 & 85 & 90 & 88 \\
7 & 75 & 75 & 75 \\
\hline
\end{tabular}

From the data on the results of student discussion in the first cycle (Table 4), there are three groups values below the minimum completeness criteria. Whereas in the second cycle, there an increase, namely all groups have reached the minimum completeness criteria value. At the end of learning every cycle, namely at the third meeting, students asked to do daily tests. From the results of daily tests as a benchmark to determine the success of student learning to determine the extent of understanding the topic momentum and impulses and collisions.

Furthermore, the results of recapitulation student learning outcomes are seen from the results of tests in cycle I and cycle II. Test carried out at the end of each cycle of this matter to see whether there is an increase or not from the results of student physics learning on momentum material and impulses and collisions - comparison of learning outcomes in cycle I and cycle II, written in Table 5. 
Table 5. Student Learning Outcomes Physics

\begin{tabular}{cccc}
\hline Aspect & Results Cycle 1 & Results Cycle 2 & Improvement \\
\hline Total student & 35 & 35 & - \\
\hline Average value & 76,57 & 78,57 & 2 \\
\hline Value $\geq \mathbf{7 5}$ & 25 & 31 & 6 \\
\hline Value $<\mathbf{7 5}$ & 10 & 4 & 6 \\
\hline \% success & $71 \%$ & $88 \%$ & $11 \%$ \\
\hline Criteria & Good enough & Very good & Good \\
\hline
\end{tabular}

Based on the results of learning physics Table 5 students from the first cycle of students completed as much as $71 \%$ or there were 25 students completed the minimum completeness criteria score. While in cycle II, there were 31 children completed $88 \%$, meaning that student learning outcomes from cycle first to cycle second had an increase of $11 \%$. The shows that students' physics learning outcomes with problem-based learning can increase. This is because using problem-based learning creates opportunities (Kusumaningtyas et al., 2019; Murray-harvey et al., 2013).

Next, Student responses to learning with problem-based learning based on the questionnaire distributed carried out at the end of each cycle after the test - analysis, and indicators of student responses presented in the form of Table 6.

Table 6. Data on Students' Response to the First Cycle of Problem-Based Learning

\begin{tabular}{lllc}
\hline \multirow{2}{*}{ No } & \multicolumn{1}{c}{ Questions } & \multicolumn{2}{c}{ Answer } \\
\cline { 4 - 4 } & \multicolumn{1}{c}{$\begin{array}{l}\text { Do you think physics learning with problem-based learning models can motivate } \\
\text { student learning }\end{array}$} & $83 \%$ & No \\
\hline 2 & $\begin{array}{l}\text { Do you think physics learning with the problem-based learning model can } \\
\text { improve collaboration with groups and friends }\end{array}$ & $54 \%$ & $46 \%$ \\
\hline 3 & $\begin{array}{l}\text { Do you think physics learning with problem-based learning can facilitate } \\
\text { understanding of a topic }\end{array}$ & $43 \%$ & $57 \%$ \\
\hline 4 & $\begin{array}{l}\text { Do you think physics learning with problem-based learning models can increase } \\
\text { interaction with other students }\end{array}$ & $66 \%$ & $34 \%$ \\
\hline 5 & $\begin{array}{l}\text { Do you think physics learning with problem-based learning models can facilitate } \\
\text { solving problems }\end{array}$ & $46 \%$ & $54 \%$ \\
\hline 6 & $\begin{array}{l}\text { Do you think physics learning with problem-based learning models improves } \\
\text { student learning outcomes }\end{array}$ & $43 \%$ & $57 \%$ \\
\hline 7 & $\begin{array}{l}\text { Do you think physics learning with problem-based learning models is fun and } \\
\text { interesting }\end{array}$ & $49 \%$ & $51 \%$ \\
\hline & \multicolumn{1}{c}{ Averages } & $54,7 \%$ & $45,3 \%$ \\
\hline
\end{tabular}

The results of the recapitulation regarding student responses (Table 6) to learning with the problem-based learning model provide a positive response that equal to $54.7 \%$ because students still confused about the tasks that must complete in learning with problem-based learning, students are less daring to express their opinions. While the results of student responses to learning with a problem-based learning model in cycle II shown in the form of Table 7 . 
Table 7. Data on Students' Response to the Second Cycle of Problem-Based Learning

\begin{tabular}{llcc}
\hline \multirow{2}{*}{ No } & \multicolumn{1}{c}{ Questions } & \multicolumn{2}{c}{ Answer } \\
\cline { 3 - 4 } & \multicolumn{1}{c}{$\begin{array}{l}\text { Yes } \\
\text { Do you think physics learning with problem-based learning models can motivate } \\
\text { student learning }\end{array}$} & $86 \%$ & $14 \%$ \\
\hline 2 & $\begin{array}{l}\text { Do you think physics learning with the problem-based learning model can } \\
\text { improve collaboration with groups and friends }\end{array}$ & $83 \%$ & $17 \%$ \\
\hline 3 & $\begin{array}{l}\text { Do you think physics learning with problem-based learning can facilitate } \\
\text { understanding of a topic }\end{array}$ & $80 \%$ & $20 \%$ \\
\hline 4 & $\begin{array}{l}\text { Do you think physics learning with problem-based learning models can increase } \\
\text { interaction with other students }\end{array}$ & $86 \%$ & $14 \%$ \\
\hline 5 & $\begin{array}{l}\text { Do you think physics learning with problem-based learning models can facilitate } \\
\text { solving problems }\end{array}$ & $80 \%$ & $20 \%$ \\
\hline 6 & $\begin{array}{l}\text { Do you think physics learning with problem-based learning models improves } \\
\text { student learning outcomes }\end{array}$ & $94 \%$ & $6 \%$ \\
\hline 7 & $\begin{array}{l}\text { Do you think physics learning with problem-based learning models is fun and } \\
\text { interesting }\end{array}$ & $94 \%$ & $6 \%$ \\
\hline & \multicolumn{1}{c}{ Averages } & $86 \%$ & $14 \%$ \\
\hline
\end{tabular}

The recapitulation of student responses (Table 8) learning with the problem-based learning model turned out to provide a positive response of $86 \%$. The shows that with problem-based learning, students become interested and happy. From the results of the first and second cycle questionnaire, there was a significant increase from $54.7 \%$ to $86 \%$, thus indicating that problem-based learning carried out in learning momentum, and impulse class X MIPA1 High School 1 Piyungan had a positive response, which could motivate learning students, enhance collaboration between friends and groups, facilitate understanding of material, improve interaction with other students, improve learning outcomes, please.

Based on student respondents in the first cycle obtained a percentage of $54.7 \%$ while in the second cycle obtained $86 \%$ who agreed or were happy with physics learning with problem-based learning. Thus there is an increase in student responses by $31.3 \%$.

From the data obtained that learning activities with problem-based learning models on momentum and impulse material can increase student activity in learning, students are easier to understand learning material and can improve physics learning outcomes of class X MIPA High School 1 Piyungan.

\section{CONCLUSION}

The learning model with problem-based learning can increase physics learning activities of class X MIPA 1 students at High School 1 Piyungan Bantul on momentum material and impulse for the 2018/2019 academic year. Increased physics learning activities of class X MIPA High School 1 Piyungan with problem-based learning in the momentum and impulse material for the 2018/2019 academic year from cycle one at the first meeting and the second meeting increased from $84.75 \%$ to $91.11 \%$ namely $6.36 \%$. In the second cycle, there was an increase from $85.28 \%$ to $91.85 \%$, an increase of $6,57 \%$

\section{ACKNOWLEDGMENT}

Our thanks to the Chief High School 1 Piyungan for providing facilities during the research process so that research can finish. 


\section{REFERENCES}

Bagus Shandy Narmaditya, W., \& Dwi Wulandari. (2017). Impact of Problem-Based Learning on Student Achievement in Economics Course. Classroom Action Research Journal, 1(1), 1-11. https:// doi.org/10.17977/um013v1i12017p1

Camacho, H., \& Christiansen, E. (2018). Teaching Critical Thinking Within an Institutionalised Problem Based Learning Paradigm - Quite a Challenge. Journal Problem Based Learning in Higher Education, 6(2), 91-109. https://doi.org/ 10.5278/ojs.jpblhe.v6i2.2308

Erda, V., Razak, A., \& Sumarmin, R. (2018). The Effect of Model Problem Based Learning of Learning Outcomes Student Course on Animal Ecology Based on Learning Styles. International Journal of Progressive Sciences and Technologies, 538(2), 533-538.

Fatmawati, Fayanto, S., Sukariasih, L., \& Heri Retnawati. (2019). Investigating the Effectiveness of Inquiry Learning and Direct Learning Models toward Physics Learning. Advances in Social Science, Education and Humanities Research, 317(IConProCS), 260-265.

Khusna, F., Syamrurizal, \& Azwir Anhar. (2018). The Effect of Problem Based Learning Model Nuanced Science Literacy Towards Junior High School Students ' Natural Sciences Learning Competence in Environmental Pollution and Global Warming Learning Materials. International Journal of Progressive Sciences and Technologies, 8(2), 129_ 134.

Kunandar. (2008). Langkah Mudah Penelitian Tindakan Kelas Sebagai Pengembangan Profesi Guru. Jakarta: Rajawali Press.

Kusumaningtyas, D. A., Nursulistiyo, E., \& Sulisworo, D. (2019). Evaluation of The ProblemBased Learning Effectiveness in The Course of Physics Curriculum Analysis. Advances in Social Science, Education and Humanities Research, 277(Steach 2018), 32-37.

Laili, F., \& Lufri, L. (2019). Assistance of Student Worksheets Based Problem Based Competence. International Journal of Progressive Sciences and Technologies, 13(2014), 118-123.
Mardian, E., \& Yerizon. (2018). Validity of Problem Based Learning Oriented Learning Tools For Senior High School. International Journal of Progressive Sciences and Technologies, 10(1), 96-102.

Mulyasa. (2011). Praktik Penelitian Tindakan Kelas. Bandung: PT Remaja Rosdakarya.

Murray-harvey, R., Pourshafie, T., \& Reyes, W. S. (2013). What teacher education students learn about collaboration from problem-based learning. Journal of Problem Based Learning in Higher Education, 1(1), 114-134.

Nana Sudjana. (2002). Cara Belajar Murid Aktif. Bandung: Sinar Baru Algenso.

Nugraha, I. S., \& Suherdi, D. (2017). Scientific Approach: an English LearningTeaching ( ELT ) Approach in The 2013 Curriculum. Journal of English and Education, 5(2), 112-119.

Nurhayati, N., \& Rosmaiyadi, R. (2017). Efforts to Improve Student's Self Confidence Using Collaborative Learning Model. Jurnal Pendidikan Matematika Indonesia, 2(2), 57-62. https://doi.org/10.26737/jpmi.v2i2.223

Rizal, M. (2015). A Classroom Action Research: Improving Speaking Skills Through Information Gap Activities. English Education Journal, 6(3), 342-355.

Shohimin. (2016). Model Pembelajaran Inonvatif dalam Kurikulum 2013. Yogyakarta: Ar-Ruzz Media.

Sudjana, N. (1995). Penilaian Proses Belajar Mengajar. Yogyakarta: PT. Rosdakarya.

Sugiyono. (2012). Metode Penelitian Pendidikan Pendekatan Kuantitatif, Kualitatif dan $\mathrm{R} \& D$. Bandung: Alfabeta.

Suyatno. (2009). Menjelajah Pembelajaran Inofatif. Sidoarjo: Masmedia Buana Pustaka.

Trianto. (2009). Mendesain Model Pembelajaran Inovatif Progesif. Jakarta: Kencana Perdana Media Group.

Warso, A. W. D. D. (2016). Publikasi Ilmiah Pembuatan Buku, Modul, Diktat \& Nilai Angka Kreditnya. Yogyakarta: Pustaka Belajar. 
Wina Sanjaya. (2010). Strategi Pembelajaran Berorentasi Standar Proses Pendidikan. Jakarta: Preneda Sanjaya. 